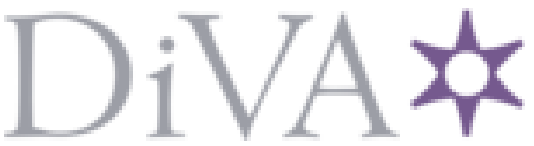

http://www.diva-portal.org

Postprint

This is the accepted version of a chapter published in Handbook of New Religions and Cultural Production.

Citation for the original published chapter:

Frisk, L. (2012)

The Anthroposophical Movement and the Waldorf Educational System

In: Handbook of New Religions and Cultural Production Leiden, Boston: Brill

Academic Publishers

Brill Handbooks on Contemporary Religion

N.B. When citing this work, cite the original published chapter.

Permanent link to this version:

http://urn.kb.se/resolve?urn=urn:nbn:se:du-5394 


\section{THE ANTHROPOSOPHICAL MOVEMENT AND THE WALDORF EDUCATIONAL SYSTEM}

Liselotte Frisk, Introduction

The anthroposophical movement originated with Rudolf Steiner (1861-1925) in Berlin 1912. The anthroposophical movement has inspired several cultural developments, the most important ones being biodynamic agriculture, holistic health care, the Waldorf educational system, architecture and art. The subject of this paper is the Waldorf educational system, which grew out of Anthroposophy in $1919 .{ }^{1}$ A friend of Rudolf Steiner and also an anthroposophist, Emil Holt, owner of the WaldorfAstoria Cigarette Factory in Stuttgart, founded the first school with anthroposophical inspiration for his workers' children. ${ }^{2}$ The school grew fast already from the beginning, and soon had many pupils from all kinds of background (Steiner 1995d: 97). After four years, it had grown to accommodate 800 students in twelve grades. In 1922, the founding of the first Waldorf school in Holland was initiated, the first Waldorf school in England was founded in 1925, and the first American Waldorf school started in 1928 (Querido 1996: vii-viii). From being 160 schools worldwide in 1977 (Carlgren 1978: 55) and 600 in 1996 (Querido 1996: viii), today there are more than 900 Waldorf schools all over the world (Association of Waldorf Schools in America n.d.). ${ }^{3}$

\footnotetext{
${ }^{1}$ Rudolf Steiner himself had a background as a teacher of history, public speaking and composition in a working class adult education centre (Steiner 1995b: 52).

${ }^{2}$ Hence the education system is called Waldorf education system, and the schools Waldorf schools.

${ }^{3}$ The development and comparative success of the Waldorf educational system could be attributed to several different causes. According to the production of culture perspective (Peterson and Anand 2004), the six-facet model of production encompasses technology, laws and regulation, industry structure, organization structure, occupational careers and the market. The development of both Anthroposophy and the Waldorf educational system has been shaped by several cooperating factors, most related to cultural and social changes in the direction of secularization, diversity, and plurality. Some of these aspects are new possibilities of mass communication (facilitating migration of cultural elements), laws opening up for religious pluralism and greater possibilities of forming alternative religious organizations (in Austria there was the 1874 law on the recognition of churches), and the slowness of response of traditional churches to changing popular tastes (because of their bureaucratic structure) compared to innovative, small and loosely structured religious organizations. Peterson and Anand also observe that individual creativity shapes culture as well (2004: 318), leaving space for the personal genius of Rudolf Steiner.
} 
In short the Waldorf educational system is based on Steiner's thoughts that the human being develops through three 7-year stages during childhood and early youth. The guiding principles are three functions or processes within the human being, i.e. will, feeling and thought, which are perceived of as working in different ways at different developmental levels. For the preschool child, will, or physical action, is the dominant function. Between seven and fourteen, feeling is the main medium, and, from fourteen to twenty-one, thought is predominant (Carlbaum 2008: 10). Creativity and art are prominent in the Waldorf schools (Liebendörfer 2008: 3), and special colours and natural materials are preferred to form the outer environment (Bjerström 2008: 4). The ambition is that the class is followed by the same class teacher from first class and well into puberty (Waldorfskolefederationen 2010).

In this paper the main principles of the Waldorf educational system are described, and the relationship between Anthroposophy as a philosophical-spiritual system and the Waldorf educational system is investigated. Annaskolan, a Waldorf school close to Garpenberg, Dalarna, a local area in northern Sweden, is used as an example and illustration. I also intend to discuss the problematic issue of the relation between the Waldorf educational system and religion. My material consists of lectures by Rudolf Steiner from the early 1920's, where he discussed the Waldorf educational system, other and more recent printed material written by Waldorf teachers and interpreters, home pages for Waldorf schools, and observations and interviews during a field study trip to Annaskolan in the autumn of 2010.

Anthroposophy and the Waldorf Education System: Early Lectures by Rudolf Steiner

Rudolf Steiner considered Anthroposophy "a spiritual science", in short an extension or continuation of natural-scientific thinking (Steiner 1995b: 33). In a lecture from 1921, he says that anthroposophical spiritual science enables us to become aware of our spirituality, and that it helps us see other humans as beings of soul and spirit, and also to recognize that our earthly deeds have cosmic and universal spiritual meaning (Steiner 1995a: 27). Spiritual science further enables us to look "with scientific accuracy" into the spiritual world where human beings live before they descend into physical existence at conception or birth (Steiner 1995b: 36). The aim of spiritual 
science is to lead humanity, in a way that corresponds to its contemporary character, over the new threshold into a spiritual world (Steiner 1995a: 14).

In working towards these aims, spiritual science has, according to Steiner, to be active not only in theory; it also has to enter the sphere of practical life. Steiner wrote that spiritual-scientific research can be applied in all branches of science, for example to medical or nutritional questions. Also architecture could flow from the same spiritual sources (Steiner 1995a: 28-30). One of the most important practical activities is, however, education of the young. According to Steiner, spiritual science provides comprehensive knowledge of the child, and seeks to create a real art of education (Steiner 1995b: 35). Steiner discussed the Waldorf school in Stuttgart, directed by himself, as a school whose pedagogical principles and methods were based on insights gained through the science of the spirit (Steiner 1995a: 28-30). Steiner also said, in another lecture, that good teachers in a Waldorf school are teachers whose entire lives have been moulded by spiritual knowledge, and that the best way of learning to know the Waldorf school and of becoming familiar with its underlying principles is by gaining knowledge of anthroposophical spiritual science itself (Steiner 1995b: 51).

However, Steiner emphasized that although the Waldorf school should take its starting point from anthroposophical spiritual science, it is not at all concerned with carrying into the school anthroposophical dogma or anthroposophical convictions. It should be neither ideological, nor sectarian or denominational. The Waldorf school applies specific methods and classroom practices, as well as pedagogical ideas and impulses drawn from anthroposophically-oriented spiritual science (Steiner 1995d: 99). The children in a Waldorf school are not taught, for example, that human beings consist also of en etheric and an astral body - but the person knowing that the human being, when observed scientifically, consists of body, soul and spirit, and grasping how this is revealed in the child as a human being in-the-making, gains a deeper and truer knowledge of the human being than is possible from natural science (Steiner 1995d: 100). Steiner said that Waldorf teachers are fully convinced that what they meet in the children, is the outer manifestation of divine and spiritual beings who have come down to earth from a purely soul and spiritual existence in order to evolve in a physical body on earth between birth and death. Waldorf teachers are thoroughly grounded in an understanding of the whole human being (Steiner 1995d: 101). The 
children have to be looked upon as beings of body, soul and spirit, if the pupils' innermost beings are to be revealed (Steiner 1995d: 102).

Observing the growing human being in an objective, scientific way, Steiner claimed, a most important thing is the gradual development of the human being through several different life periods. One of those periods extends from birth to the change of the teeth, when it is evident that forces from within drive the second teeth out of the organism; that is, until about the seventh year. This is, however, only a physical aspect; there are parallel developments occurring alongside these physical changes. The child's entire soul life undergoes a gradual change during this period. The child, who previously could form only blurred and indistinct concepts, now begins to form more sharply contoured concepts. Also, a different kind of memory is unfolding (Steiner 1995b: 37). With the change of teeth around the seventh year, the child begins to be active in the realm of mental imagery, in forming simple thoughts, and in the sphere of conscious will activity (Steiner 1995b: 38).

In the first period of life, Steiner said that the child, descending from the spiritual world, brings to outer expression - like an echo from the spiritual world - the last experiences undergone there. This first period of life the child is an "imitating" being. They copy what is done before them with their movements. For example, they learn to speak entirely through imitation. And, until they lose their milk teeth, they also imitate what happens morally in their environment. An education system has, according to Steiner, to respect this fundamental principle of imitation, active during the child's first seven years. During this period, the teacher has to guide the child by his/her own deeds and by setting an example. This is valid not only for actions, but also for thoughts and feelings. Steiner said, that if children enjoy the company of grown-ups who never allow unworthy thoughts or feelings to enter into their lives, something noble and good could become of them (Steiner 1995b: 41-43). Until the age of seven, every child is a universal sense organ that relates as an organism to the surroundings. Until the seventh year, impressions are received from the surroundings as if the child's whole being were one large sense organ (Steiner 1996c: 134).

During the second period of the child's life, from seven years to around fourteen (the end of the period marking the beginning of puberty) a new impulse, according to Steiner, emerges from the child's soul. The child now wishes to regard the teacher as a figure of undisputed authority. Steiner did not like the contemporary tendency to democratize schools, as he says that this goes against the human nature at 
this age. ${ }^{4}$ At this age, the child has a deep desire to learn what is right or wrong, good or evil, from a beloved and naturally respected authority figure. Only in this way will the right sense of freedom within the child develop later. During this period, the child also makes a gradual transition from living in mental images to a more intellectual approach (Steiner 1995b: 44-45). It is important, during these years, to educate, instruct and train the child's will. To unfold the child's will nature, an artistic approach, for example through music, should be employed (Steiner 1995e: 176-179). An artistic element should underlie all teaching and education from the change of teeth to puberty (Steiner 1995f: 211). In a lecture from 1923, Steiner also argued that the child between seven and fourteen has to be introduced in a living way to the Christ along the lines of an education out of Anthroposophy, otherwise the youngster will either deny the Christ or will hold on to a traditional faith by means of which he or she cannot truly experience the Resurrected One (Steiner 1996b: 122).

An important turning point, said Steiner, occurs around the child's ninth year (but could also be later, during the tenth or eleventh year). When the teacher recognizes that a child is passing this point, the teacher also changes pedagogy. This is the period when the child learns to differentiate between self and surroundings, and no longer experiences itself as an organic part of its environment, but as a separate, independent entity. Prior to this point, the child lives in a world of pictures, and in assisting the child to establish its relationship to the world at this stage, the teacher has to use a pictorial approach. Instead of beginning with the letters of the alphabet, the children are encouraged to paint and draw, to work with colours and forms. Then the actual letters are allowed to emerge out of these colour-filled forms. The children should first learn to write, and then to read. It is important to develop the abstract element gradually and with the artistic element as a base (Steiner 1995b: 46-47).

By the eleventh or twelfth year, the forming of concepts by the awakening intellect starts (Steiner 1995b: 48). Before the twelfth year, subjects like mineralogy, physics, and chemistry should not be introduced. The only intellectual occupation not harmful during the earlier ages is arithmetic, because it is directly connected with an inner discipline and because it is neutral with regard to the cultivation of both will and heart

\footnotetext{
${ }^{4}$ Steiner wishes to emphasize that he does not support a reactionary social belief in authority, but that the ideal of the teacher as an authority is set up just for educational purposes, for this age group, and that it originates from a deeper understanding of human nature (Steiner 1995d: 110).
} 
or soul (Steiner 1995e: 186-187). Everything taught before the twelfth year should be based upon art and rhythm (Steiner 1995f: 211).

From the onset of puberty ${ }^{5}$ (around the age of fourteen) the teachers should try to awaken the students' interest for what is happening in the world, for such subjects as geography and history, subjects that lead students away from themselves and out into the world (Steiner 1995c: 90). At this time, the teacher should try to cultivate in the young people religious feelings, not in any sectarian way, but in the sense that they acquire the seriousness necessary to recognize that the physical world is everywhere permeated by spirit (Steiner 1995d: 121). Practical subjects are also important from the onset of puberty, crafts which at the same time demand an artistic treatment (Steiner 1995e: 187). Only after puberty, one's relationship to the world is appropriate for judging it intellectually. After puberty, we are intellectual beings (Steiner 1996a: 10).

An important feature that Steiner talked about is how days should be structured in Waldorf schools. In the Waldorf school, for three or four weeks the same lesson subject should be taught each morning between eight and ten, so that the students can fully concentrate on and live in one main lesson subject (Steiner 1996d: 160).

Concerning religious education, Steiner wrote that religious lessons should be given by members of different religious denominations. Roman Catholic children should receive religious education from Roman Catholic priests, and Protestant children from Protestant ministers, and so on. However, in the first Waldorf school in Stuttgart, many of the first students had parents who were religious dissenters. For these children, Steiner introduced "free" Christian religious lessons - that is, free of established denominations - which he says worked very well. Steiner further says that the teachers themselves should be permeated with a religious mood, so that the religious mood could arise spontaneously in the children. A religious atmosphere can, according to Steiner, be created in every lesson and subject. When teachers, through their own soul mood, connect everything that exists in the sensory world to the supersensible and divine, everything they bring to their classes will naturally transcend the physical. Eventually, through the right cultivation of the religious mood,

\footnotetext{
${ }^{5}$ The school-leaving age in Germany in 1921 was fourteen years (Steiner 1995d: 120). It is perhaps therefore quite natural, that Steiner in his lectures from this time speaks mostly about the first two periods of the child's life.
} 
the children will experience moral impulses as the divine speaking in human nature and in the human being (Steiner 1996e: 182-184).

In the Waldorf school, one of the important subjects is eurythmy, which Steiner explained as a new art of movement, cultivating body, soul and spirit, a visible form of language and music (Steiner 1995d: 124). Anthroposophy holds that, if a child practices the appropriate movements of the body at an early age, he or she will develop intelligence, intellect, the power of reasoning and the ability to discriminate at a later age (Steiner 1995e: 180). Instead of marks, the children receive written reports from the teachers, in which the teachers express in their own style how the pupil has fared during the year. Each report thus contains its own individual message. The report ends with a little verse, specially composed for each child, epitomizing the year's progress (Steiner 1995d: 136).

Waldorf Education in Practice - Annaskolan: A Small Waldorf School in Sweden ${ }^{6}$

Annaskolan, a small Waldorf school in the village Dormsjö, close to Garpenberg, Dalarna, ${ }^{7}$ Sweden, is one of the around forty Waldorf schools in Sweden. ${ }^{8}$ Annaskolan has forty-eight pupils of ages between seven and sixteen years. The school was founded in $1987,{ }^{9}$ as a school for children whose parents worked at the nearby Dormsjöskolan, a school for learning disabled children, founded in 1958 on anthroposophical principles (Stridell 2008: 5-17; 105). The number of pupils has, however, during the last few years been continually decreasing: in 2001-2002 it reached its peak with 86 pupils, whereas today the number of pupils is only a little more than half of that (Stridell 2008: 105). The comparatively low number of pupils is

\footnotetext{
${ }^{6}$ The material in this section was gathered on October 11th, 2010, at a field study visit to the school. Notes from observations, interviews and informal talks are used. The section has been read and acknowledged by the head master of the school, Elisabeth Norman, who was also one of the interview subjects.

${ }^{7}$ This study is also a part of a research project with financial support from The Swedish Research Council, called "The meditating Dala horse". In this project, all activities with some kind of religious connotations in the area of Dalarna were mapped. Dalarna is a semi-rural area with around 270,000 inhabitants, situated around $300 \mathrm{~km}$ north of Stockholm. I conduct this project together with my colleague Peter Åkerbäck, Stockholm University.

${ }^{8}$ In Sweden, so called "free schools" (schools not run communally but privately) are permitted. They receive economic state support and have to follow the basic communal school curriculum. The Waldorf schools are classified as alternative educational style schools (and not as religious schools, which is another category).

${ }^{9}$ There was a nursery school already from 1981 (Stridell 2008: 105).
} 
a worry for the school, which would actually need around one hundred or at least seventy-five pupils to be economically sustainable.

\section{The morning assembly}

Monday morning at Annaskolan begins with a meeting for all children and all teachers, where everyone sits together in a circle. Everyone present is, by a small song, named and recognized, and it is noted who is not there and why. As it was autumn when we visited, among other songs an autumn song was sung. We were told that songs, chants and rhythms are important parts of the Waldorf education, especially at younger ages, but are also used in the upper classes. One morning speech, originating from Rudolf Steiner, was cited at the morning assembly with the text (free translation):

\footnotetext{
Admire the beautiful

and love the true

Decide the good

and revere the noble

That leads us humans

to a true goal in life

To right in our action,

to peace in our feeling,

to light in our thought

And teaches us to perceive

that everywhere exists

the prevailing wisdom of God

In the space of everything,

in the foundation of the soul
}

At the end of the morning assembly, the classes left one by one, together with their class teacher.

The structure of the day and the year

Rhythm is important in life in several ways, according to the Waldorf educational system. Both the year and the day follow a certain rhythm. The yearly seasons are 
observed in the Waldorf schools, as well as yearly festivities like the traditional Michael festivitiy ${ }^{10}$ in autumn.

Will (activity), feeling (creativity) and thinking are the base pillars in the Waldorf education, and are also the focus at Annaskolan. Will, feeling and thinking interact and all three are important to create a whole human being. The communal education system, however, gives priority mostly to the intellectual (thinking) part, whereas in Waldorf education feeling and will both occupy important spaces. Handicraft and smithery (will) are important parts of the education, as well as different kinds of art like painting and music (feeling). All pupils in Annaskolan start playing flute in first class, and there are special rooms for different kinds of handicraft.

According to the schedule in Annaskolan, during the morning period one subject having to do with thinking is focused between $8: 15-9: 45 \mathrm{am}$ for three or four weeks at a stretch. It could be mathematics, writing, history, geography, physics, or social science. From 10:10am to lunch time, feeling is focused, through for example language, music or eurythmy. During this time of our visit, we observed a class of eurythmy with a group of nine and ten year-old pupils. According to the teacher, eurythmy is a way of visualizing spirituality. Handicraft, which is will-oriented, is practiced in the afternoon, after lunch served with biodynamically cultivated ingredients. Handicraft could for example mean sewing, wood work, house building, smithery, or ceramics.

The perspectives on different subjects follow the different ages. For example, history is taught by fairy tales in the first grade, legends and fables in the second grade, the Old Testament is taught in the third grade, and after that in sequence Norse mythology, Greece, Rome and then, in the seventh grade, the Renaissance period. It was explained to us that the seventh grade is a time of emancipation from the parents and discovery of the world around, and therefore the Renaissance, with the great voyages of discovery and the development of astronomy, is considered a suitable time period to learn about at this age.

In the Waldorf schools, there is an emphasis on stories and verbal and dramatic representations. In the class rooms for the younger ages, there are cosy corners where

\footnotetext{
${ }^{10}$ Michael is an arch angel and was traditionally celebrated on this day, which from old was considered as the border between summer and winter. In the Waldorf schools, a drama is often performed on the theme Saint George and the dragon.
} 
everyone can sit on the floor and listen to stories of different kinds. There are also artistic decorations, like, at the time of our visit to Annaskolan, there were autumn altars in some of the class rooms, with artistic compositions of autumn leaves and autumn attributes.

According to several of the teachers at Annaskolan, actually all Waldorf education could - but not necessarily does - touch upon spirituality. Spirituality is, according to them, not connected to religion, but something that points to the higher self in the human being. According to our interview subjects, spirituality is connected to invisible qualities which are not possible to touch or see, for example the perfect wholeness of the number one in mathematics. But teachers do not talk about spirituality with the children. Some of them do, however, try to transmit a feeling of thankfulness and reverence to the nature and the universe. The subjects are considered tools for this.

\section{The outer environment}

Colours in the anthroposophical movement are held to influence the human beings in different ways. Characteristically, the class rooms of different ages are painted in different colours in all Waldorf schools, as children of different ages need different colours for optimal influence. For small children, red is considered the optimal colour. After red comes orange, then yellow, then green and then blue, which is supposed to promote thinking. A transparent glazing paint is used for the walls.

Annaskolan also has a profile of open air life, and the children are outside very much. At the time of our visit, one group of pupils was outside on the fields nearby, where food for the school lunch is grown, to study the biodynamic agriculture. Another group of smaller children were riding ponies, owned by one of the Waldorf teachers.

\section{The teachers and the children}

Annaskolan is formed as a foundation. Ten teachers work part time in the school, several of them are also parents to pupils. About one third of the teachers have completed the Waldorf teacher education, and all others but one have at least some kind of Waldorf teacher education. Several teachers have some kind of anthroposophical background, although not all of them would call themselves anthroposophists. The wages are lower than the average teacher wages in Sweden, so 
working as a Waldorf teacher could also be seen partly as a non-profit oriented engagement. The parents are supposed to help with cleaning and other tasks.

At inquiry, we found that very few of the children came from the nearby local village and local town, Garpenberg and Hedemora. Instead, several of them travelled quite large distances to come to their school, some children as far as $70 \mathrm{~km}$ one way. Some children also belonged to families which had moved to live close to the school, and whose parents also worked there. It seemed that the Waldorf school, in the case of Annaskolan, was not so much a local alternative for local residents as an alternative selected by very engaged parents, originally from other parts of Sweden.

At the time of our visit, the number of girls substantially outnumbered the number of boys at the school. The teachers explained this by the emphasis on aesthetic subjects, which seems to attract more girls. They did not, however, think about this as a pattern at the school but rather just as a coincidence.

One of the teachers also had a priest education in the anthroposophical inspired congregation the Christian Community. There is, we learnt, a congregation of the Christian Community, related to Annaskolan and Dormsjöskolan. At divine service once a month, there are usually ten to twenty persons attending. Once a week, nine pupils from the $7^{\text {th }}$ and $8^{\text {th }}$ degree (about half of the pupils in these grades) study at Christian Community for the confirmation ritual.

\section{Discussion}

Criticism about the Waldorf educational system seems to have been around already from the beginning, judging from the way Rudolf Steiner presented some issues in his lectures from the $1920 \mathrm{~s} .{ }^{11}$ There seem to have been worries already at that time about the close relation between the Waldorf educational system and Anthroposophy, and how that might reflect in the educational praxis.

In Sweden, public debates have been sparked relating to these issues on several occasions during the years the Waldorf schools have existed. One book was published in 1990, by a father whose child was at that time attending a Waldorf school in the

\footnotetext{
${ }^{11}$ Like it is the case also today with new religious movements, mass media seems to have played a key role in the reception of Anthroposophy and the Waldorf educational system. For more theoretical reflections on the role of mass media in blocking or facilitating new cultural expressions, see Hirsch 1972.
} 
middle part of Sweden. His main argument against the Waldorf educational system is that according to him it presents a false image of being neutral to religious issues, whereas in reality the children are subject to religious indoctrination. The basic theory of the Waldorf educational system, the developmental stages of the child, and the three basic processes of human being, he criticizes as not being built on research, as is claimed, but instead having been revealed to Steiner by spirits (Wilson 1990: 28). He further claims that the morning and afternoon prayers routinely conducted in the schools should be considered as religious practices. Another example is, he says, that the Old Testament in Waldorf schools is considered part of the history subject, and that the truth of the Old Testament is not allowed to be questioned (Wilson 1990: 1819). He illustrates with his daughter, who at the age of nine seemed to have some problems. The teacher in the Waldorf school attributed the child's problems to the fact that her father questioned the Old Testament at home, and that the child therefore became mentally divided and confused. In a letter to the father, the teacher wrote that the world for the child of this age has to be as whole as possible, and that the school and the home should cooperate to achieve this (Wilson 1990: 13-14). When the child was ten, the father was called to the school to discuss an urgent problem with his child. He was very worried, until he understood that the urgent problem was that the child did not pronounce the prayers at school, but just moved her lips (Wilson 1990: 16). He also criticizes the so called "confession free" religious education, which he says in Waldorf schools means Christian religious education, however not connected to any specific Christian denomination (Wilson 1990: 22-23).

Below, some of the critical issues connected to the Waldorf educational system are brought up for discussion. The three areas to be discussed are: The relation between Anthroposohy and Waldorf education; the role of the teacher; and the relationship between Anthroposophy, the Waldorf educational system, and religion.

\section{The relation between Anthroposophy and Waldorf education}

The close connection between Anthroposophy and the Waldorf educational system is evident, and is referred to in all available sources. In the words of Rudolf Steiner, the Waldorf educational system is a practical adaptation of the spiritual science of Anthroposophy. However, Steiner also emphasised that Anthroposophy as an ideology should not be taught in the Waldorf schools. It is just the methods and 
pedagogical ideas in the Waldorf schools which, according to Steiner, are inspired by the anthroposophical understanding of the human being.

The degree to which Anthroposophy is present in the Waldorf schools is a complicated question. There are different dimensions which have to be considered, some of which are discussed under the subsequent headings. Concerning the methods and pedagogical ideas I would, however, like to suggest a differentiation between intention and reception. A practice may have different meaning and significance for different persons, depending on if it is connected to an ideological framework (and which ideological framework) or not. The special learning-to-read-system in the Waldorf schools, for example, derived from the anthroposophical ideology, will have a different meaning for the teachers, who understand it from the anthroposophical context, connected to the child's developmental stages, and for the children (and some of the parents) who do not. The same thing is valid for other parts of the Waldorf educational system. For example, the reasons to study intellectual subjects in the morning, emotional subjects at midday, and handicraft in the afternoon are based on the anthroposophical ideology. But just the habit to practice handicraft in the afternoon does not by itself make it Anthroposophy, if ideological explanations and interpretations are absent. For the children, if the anthroposophical ideology has not been presented for them, the practical experiences of the Waldorf educational system would thus be disconnected from the anthroposophical ideology.

Thus, although the Waldorf educational system derives from the anthroposophical ideological system, the practical expressions alone may not necessarily be understood as being connected to Anthroposophy by persons lacking the ideological background. However, if the children also come into contact with anthroposophical teaching, at home for instance, the matter is of course a different one.

\section{The importance of the teacher}

As noted above, the teacher has a quite crucial role in the Waldorf educational system, and it is evident that Rudolf Steiner preferred that the teachers had an anthroposophical background. As we see from the example of Annaskolan, the teachers often also have that. According to Steiner, good teachers in a Waldorf school are teachers whose entire lives have been moulded by spiritual knowledge. The teachers should, Steiner says, have the attitude to the children as being the outer 
manifestation of divine and spiritual beings. Steiner also said that the teacher should try to cultivate in the young people religious feelings, not in any sectarian way, but in the way that they would recognise that the physical world is everywhere permeated by spirit. From the field study at Annaskolan, we understood that several of the teachers aim at expressing a spiritual orientation, related to a feeling of thankfulness and reverence to nature and the universe, and to the higher self in the human being, in their teaching and in the ways they deal with the school subjects and the children. This is another dimension of expressing Anthroposophy, which might potentially also influence the children.

Ideally in the Waldorf education, the children should keep the same teacher for several years. This is surely a trait that many parents (in Sweden at least) find attractive, as this may give the child a security some parents find lacking in the communal school, where there are different teachers for different subjects, and different teachers for different age levels. In the Waldorf educational system, however, there are additional reasons for having one and the same teacher throughout the years. As we learnt from the lectures by Steiner, during the first seven years the teacher should be an object of imitation, not only in actions, but even the teacher's thoughts and feelings are supposed to influence the child. Thus also the possible inner (spiritual) orientation of the teacher is supposed to be transmitted to the child. In the second period, from seven to fourteen years, the teacher is meant to be an authority figure, which could also be seen as a way to transmit certain orientations. The conflict between the father and the Waldorf school described above, is thus part of a larger context, where a conflict is expressed between the Anthroposophical view that an authority is necessary for the child's development at a certain age, and the ideal of critical thought in our secular society.

A long term relationship with other adults than the parents, especially adults with the self understanding of being examples and authorities for the children, quite naturally have a potential to influence a young person. Research also shows that some children from the Waldorf schools become anthroposophically engaged ${ }^{12}$. They are,

\footnotetext{
12 There are problems with the definition "anthroposophically engaged" and also with differences in how the studies were made. Frisk (1993) interviewed self defined anthroposophists, and investigated how many of these had been studying at a Waldorf school. The other two studies investigated how many of pupils in Waldorf schools continue with professional training connected to Anthroposophy. Of course, some people may consider themselves anthroposophists without taking any kind of further anthroposophical professional training. How many Waldorf pupils who chose an anthroposophical orientation in life, other than professional training, was not investigated in these two studies.
} 
however, numerically quite few (see Frisk 1993: 152-153; Dahlin et al 2006: 59; Wilson 1990: 83). There is also, in these cases, no information about in how many cases the parents were anthroposophists. As we see in the case of Annaskolan, several parents sending their children to Waldorf schools are themselves anthroposophists. An interesting fact is that around half of the children in Annaskolan who are of age attend the confirmation teaching of the anthroposophical congregation, the Christian community. A guess is that this is probably attributed more to anthroposophical parents than to teachers. However, the potential influence on children of a long-term teacher should not be underestimated.

\section{Anthroposophy, Waldorf education and religion}

Anthroposophy is self designed as a "spiritual science", and the representatives do not want to connect Anthroposophy to the term "religion". ${ }^{13}$ The meaning of the concept of religion could of course be discussed. Anthroposophy, however, fulfils several of the main criteria present in the most common definitions of religion. For example, humans are seen as having non-physical and non-mental parts which live in a spiritual world before birth. Rudolf Steiner also said that whatever we do in this world has a greater cosmic and universal spiritual meaning. Steiner, however seldom used the word "God", often speaking instead about "spiritual" and "divine", concepts closely connected to religion. Christ is seen as a central being in Anthroposophy, and his life on earth as a crucial event for humanity. Thus my conclusion is that it is quite uncontroversal to see Anthroposophy as a whole as a religious movement, in the conventional use of the term, although it is not an emic term used by anthroposophists themselves.

Even if Anthroposophy as a whole should be seen as a religious system, it could be disputed if the specific anthroposophical principles which the Waldorf schools build upon should be seen as religious or not. They derive from a clearly religious system, and of course cannot be seen as "scientific" in the sense we use and should use the term. ${ }^{14}$ Maybe they could at best be perceived of as theories about how human beings work. I would suggest that, just as disconnected practices by

\footnotetext{
${ }^{13}$ Thus following a discourse, also popular in other contexts, of the concept of religion meaning something negative, dogmatic, stiff and limiting for the human being, while "spirituality" means quite the opposite.

${ }^{14}$ It has been quite common that new religious systems since the time of Swedenborg legitimate themselves through calling themselves "scientific". It is simply another way of saying that this system is "true" and "modern", and not connected to imagination and false beliefs.
} 
themselves are not necessarily to be seen as anthroposophical, disconnected hypotheses according to which, for example, human beings develop mostly by feelings from the ages from seven to fourteen, or that art is important for the wholeness of the human being, could hardly by themselves be called religious. However, it is of course possible to make connections from these hypotheses to other parts of Anthroposophy, which are more obviously on the religious side, for the person who wants to.

There are, however, other features in the Waldorf schools which have more distinct religious dimensions. Firstly, some of the songs and chants, as the one from Annaskolan cited earlier in the text, have the character of prayers, and even God is mentioned in some of them. Secondly, another important feature with religious dimensions is the religious education itself. In Waldorf education, Steiner wrote that Christ should be introduced "in a living way" so that the young people will be able to experience him. Probably the idea to have a "confession free" (non-denominational) Christian education was a radical idea in the 1920s; today, however, in a more global era, it is very different from the confession free religious education that is the norm in Swedish schools today. Thirdly, as the father in the book referred to above notes, the Old Testament seems to be taught within the subject of history. I am not sure, however, how much this feature should be stressed as a part of "confessional religion". It probably depends on how it is done, and with what purpose, which may also vary between different schools. For example, also Norse mythology seems to be part of the history subject, at least at Annaskolan.

The conclusion, however, must be drawn that some religious features are present in the Waldorf schools today. They do not, however, seem to have a predominant role in an educational system otherwise oriented towards creativity and artistic expressions.

\section{Conclusion}

The Waldorf educational system was created almost a hundred years ago. Although deriving from the anthroposophical religious system, my main argument in this paper is that the practical aspects inspired by the anthroposophical principles used in the Waldorf educational system are not in themselves necessarily neither 
anthroposophical, nor religious. Depending on the wider context of the child, they could, however, be both.

To express a "spiritual" inner orientation in the education process seems to be important for several of the Waldorf teachers. In their self understanding, it is neither, however, a "religious" nor a "denominational" orientation. To an outsider, it is at least to be understood as "anthroposophical." There are, however, no indications so far that a great amount of pupils from the Waldorf schools become anthroposophists themselves, although more research is needed on this subject.

At the time of the creation of the Waldorf educational system, when religious education in schools was habitually denominationally confessional, it was no doubt a radical idea to initiate a "free Christian" religious education. Today, however, this orientation is quite different from the contemporary situation where a nonconfessional religious education is the norm, at least in Sweden. It is an open question if the Waldorf educational system could be open for changes and modernization or not. If it could, it might be a constructive reflection to rethink the religious aspect of education so that it will be better suited to our contemporary culture.

It would also probably be healthy if parents thinking about sending their children to Waldorf schools would have greater knowledge about the wider context of the Waldorf educational system and the background of anthroposophy. From this wider knowledge, they could on a more informed basis decide what course is best for them and their children.

To conclude, the Waldorf educational system is an innovative and creative cultural expression of the religious/spiritual system of anthroposophy, having an ambivalence towards being interpreted in a spiritual or religious sense or not. Appreciated by some, and questioned by others, the Waldorf educational system could be seen as a semi-secular adaptation of an originally religious ideology, quite successful and widespread in our contemporary time.

References 
Bjerström, Monika. 2008. "Waldorfpedagogik i förskoleåldern.” In En introduktion i Waldorfpedagogik: Barnets utveckling från förskola till gymnasium. Kursplanen i Waldorfskolan. Stockholm: Levande Kunskap Stockholm AB.

Carlbaum, Christer. 2008. "Waldorfskolan - en utvecklingsväg. En vandring genom årskurserna." In En introduktion $i$ Waldorfpedagogik: Barnets utveckling från förskola till gymnasium. Kursplanen $i$ Waldorfskolan. Stockholm: Levande Kunskap Stockholm AB.

Dahlin, Bo, Ingrid Liljeroth and Agnes Nobel. 2006. Waldorfskolan - en skola för människobildning? Slutrapport från projektet Waldorfskolor $i$ Sverige. Forskningsrapport Karlstad University Studies, 2006. Karlstad: Karlstads Universitet.

Frisk, Liselotte. 1993. Nya religiösa rörelser $i$ Sverige: Relation till samhället/världen, anslutning och engagemang. Åbo: Åbo Akademi.

Hirsch, Paul M. 1972. "Processing Fads and Fashions: An Organization-Set Analysis of Cultural Industry Systems.” In American Journal of Sociology, Vol. 77, No 4. Pp 639-659.

Liebendörfer, Örjan. 2008. "Lek, konst och levande kunskap." In En introduktion $i$ Waldorfpedagogik: Barnets utveckling från förskola till gymnasium. Kursplanen i Waldorfskolan. Stockholm: Levande Kunskap Stockholm AB.

Peterson, Richard A. and N. Anand. 2004. "The Production of Culture Perspective." Annual Review of Sociology, Vol. 30. Pp 311-334.

Querido, René. 1996. "Introduction.” In Waldorf Education and Anthroposophy 2. Twelve Public Lectures. November 19, 1922-August 30, 1924. Hudson, N.Y.: Anthroposophic Press.

Steiner, Rudolf. 1995a. "Anthroposophical Spiritual Science and the Great Questions of our Present Civilization (Spiritual Science and Waldorf Education I)." The Hague, February 23, 1921. In Waldorf Education and Anthroposophy 1. Nine Public Lectures. February 23, 1921-September 16, 1922. Hudson, N.Y.: Anthroposophic Press. 
Steiner, Rudolf. 1995b. "Education and Practical Life from the Perspective of Spiritual Science (Spiritual Science and Waldorf Education II).” The Hague, February 27, 1921. In Waldorf Education and Anthroposophy 1. Nine Public Lectures. February 23, 1921-September 16, 1922. Hudson, N.Y.: Anthroposophic Press.

Steiner, Rudolf. 1995c. "Knowledge of Health and Illness in Education." Dornach September 26, 1921. In Waldorf Education and Anthroposophy 1. Nine Public Lectures. February 23, 1921-September 16, 1922. Hudson, N.Y.: Anthroposophic Press.

Steiner, Rudolf. 1995d. "The Fundamentals of Waldorf Education.” Aarau, November 11, 1921. In Waldorf Education and Anthroposophy 1. Nine Public Lectures. February 23, 1921-September 16, 1922. Hudson, N.Y.: Anthroposophic Press.

Steiner, Rudolf. 1995e. "Educational Methods Based on Anthroposophy, Part II." Christiania (Oslo), November 24, 1921. In Waldorf Education and Anthroposophy 1. Nine Public Lectures. February 23, 1921-September 16, 1922. Hudson, N.Y.: Anthroposophic Press.

Steiner, Rudolf. 1995f. "Education and Drama." Stratford-on-Avon, April 19, 1922. In Waldorf Education and Anthroposophy 1. Nine Public Lectures. February 23, 1921-September 16, 1922. Hudson, N.Y.: Anthroposophic Press.

Steiner, Rudolf. 1996a. "Education and Teaching." London, November 19, 1922. In Waldorf Education and Anthroposophy 2. Twelve Public Lectures. November 19, 1922-August 30, 1924. Hudson, N.Y.: Anthroposophic Press.

Steiner, Rudolf. 1996b. "Why Base Education on Anthroposophy? (Part Two)." Dornach, July 1, 1923. In Waldorf Education and Anthroposophy 2. Twelve Public Lectures. November 19, 1922-August 30, 1924. Hudson, N.Y.: Anthroposophic Press.

Steiner, Rudolf. 1996c. "Waldorf Pedagogy.” Ilkley, August 10, 1923. In Waldorf Education and Anthroposophy 2. Twelve Public Lectures. November 19, 1922August 30, 1924. Hudson, N.Y.: Anthroposophic Press. 
Steiner, Rudolf. 1996d. "Anthroposophy and Education.” The Hague, November 14, 1923. In Waldorf Education and Anthroposophy 2. Twelve Public Lectures. November 19, 1922-August 30, 1924. Hudson, N.Y.: Anthroposophic Press.

Steiner, Rudolf. 1996e. "Moral and Physical Education." The Hague, November 19, 1923. In Waldorf Education and Anthroposophy 2. Twelve Public Lectures. November 19, 1922-August 30, 1924. Hudson, N.Y.: Anthroposophic Press.

Stridell, Esbjörn. 2008. Dormsjöskolan: Aterblick på ett lärorikt halvsekel. Garpenberg: Föreningen Dormsjöskolan.

Wilson, Gösta. 1990. Jag trodde på Waldorfskolan: En inträngande analys av Waldorfpedagogiken. Örebro: no publisher.

Electronic material

Waldorfskolefederationen. "Waldorf i Korthet." Waldorf Skole Federationen. 2010, at http://www.waldorf.se/index.php?option=com_content\&view=article\&id=13\&Itemid $\underline{=16}$, accessed 6 January 2011 .

Association of Waldorf Schools in America. "Waldorf History." Why Waldorf Works. n.d., at http://www.whywaldorfworks.org/02 W Education/history.asp, accessed 3 January 2011. 